\title{
DIFFERENT EFFICACY OF NANOPARTICLE AND CONVENTIONAL ZnO IN AN ANIMAL MODEL OF ANXIETY
}

Received December 18, 2012.

\begin{abstract}
As has been shown, trace element supplementation by zinc, e.g., in the form of zinc oxide $(\mathrm{ZnO})$, can significantly influence the anxiety level. We investigated the effects of $\mathrm{ZnO}$ in the form of nanoparticles (NPs) in comparison with conventional $\mathrm{ZnO}(\mathrm{cZnO})$ in an animal model of anxiety. Adult male Wistar rats were divided into seven groups, control (receiving $0.9 \%$ saline) and six groups receiving 5, 10, and $20 \mathrm{mg} / \mathrm{kg} \mathrm{ZnO} \mathrm{NPs} \mathrm{and} \mathrm{5,} \mathrm{10,} \mathrm{and} 20 \mathrm{mg} / \mathrm{kg}$ cZnO. All drugs dispersed in $0.9 \%$ saline were injected i.p.; 30 min later, the anxiety level was estimated according to the results of the elevated plus maze test. ZnO NPs $(5 \mathrm{mg} / \mathrm{kg})$ and $\mathrm{cZnO}(10$ and $20 \mathrm{mg} / \mathrm{kg}$ ) significantly increased the normalized values of time spent in open arms (open arm time, OAT, \%) in comparison with the control group $(P<0.05)$. This is indicative of the anxiolytic effects of these components; in addition, $20 \mathrm{mg} / \mathrm{kg} \mathrm{ZnO} \mathrm{NPs}$ reduced the intensity of locomotor activity $(P<0.05)$. The serum zinc concentration was increased manifold by anxiolytic doses of the components. All doses increased serum $\mathrm{pH}$ to 8.05-8.10 and kept this index constant for $24 \mathrm{~h}$. These results indicate that the anxiolytic effect of $\mathrm{ZnO}$ NPs is much more intense than that of conventional $\mathrm{ZnO}$, but the introduction of $\mathrm{ZnO} \mathrm{NP}$ as a new drug for the treatment of anxiety disorders needs further investigations.
\end{abstract}

Keywords: anxiety, nanoZnO, plus maze, rats.

\section{INTRODUCTION}

Anxiety disorders, being a common mental health problem in the general population, affect up to $18 \%$ of individuals within a given time period and $25 \%$ of the individuals over their lifetime [1]. Generalized increases in the level of anxiety tend to precede depression and eventually develop into depression. Unfortunately, current drug therapies for psychological disorders are frequently not very successful, and many patients either do not respond to these treatments or suffer from side effects [2].

Zinc, an important prevalent trace element, is essential for both brain and systemic physiology. It has been found in a great number of protein structures, including important enzymes regulating a wide variety of cellular processes (e.g., cell division, DNA synthesis, etc.) and cell signaling pathways [3]. Zinc

\footnotetext{
${ }^{1}$ Department of Biology, Faculty of Sciences, Shahid Chamran University, Ahvaz, Iran.

${ }^{2}$ Department of Pharmacology, Faculty of Veterinary Medicine, Shahid Chamran University, Ahvaz, Iran.

Correspondence should be addressed M. Kesmati

(e-mail: m.kesmati@scu.ac.ir).
}

modulates functions of many receptors (including AMPA/kainate, NMDA, and GABA receptors) and of voltage-gated calcium channels [4-6].

During the past 50 years, it has been found that zinc deficiency in human populations is rather common, and nutritional deficiency of zinc affects many people in developing and developed countries [7]. A few studies showed that zinc deficiency induces anxietylike behavior in animals. Also, studies on rodents (rats) suggest a causative role for zinc deficiency in the induction of depressive-like symptoms, reduced physical activity, anxiety, and anorexia [8]. Data presented by Whittle et al. [9] showed that dietary zinc deficiency in mice induces anxiety-related behavior in the novelty-suppressed feeding test and enhances the latencies of food consumption. Feeding with some zinc supplements, such as $\mathrm{ZnSO}_{4}$, conventional $\mathrm{ZnO}(\mathrm{cZnO})$, and zinc methionine, was effective in reducing anxiety in rats [10]. For many years, feed manufactures prefer to use oxides of trace minerals (including zinc). Zinc oxide contains a greater concentration of this cation, as compared to sulfate, and $\mathrm{cZnO}$ is less toxic in comparison with other $\mathrm{Zn}$ compounds $[11,12]$. 
With the development of nanotechnology, the use of nanoparticles (NPs) to replace usual-scale particles has increased rapidly [13]. Manufactured NPs can be organic (polymers) or inorganic, such as nano powders of metal oxides and metal salts. Metal oxide NPs are the most frequently produced nanomaterials [14]. $\mathrm{ZnO}$ NPs constitute the extensively used engineered metal oxide nanomaterial; due to their unique optical, catalytic, semiconducting, piezoelectric, and magnetic properties, they are widely produced and technologically applied [15]. Recently, ZnO NPs have attracted the attention of biotechnologists, as they can be surface-functionalized with a wide range of metal and semiconductor core materials, thereby imparting useful properties with potentially wideranging therapeutic applications [16]. ZnO NPs can be ingested directly in food, used in food packaging, and as drug delivery agents. This $\mathrm{ZnO}$ form is used in the food industry and in biomedical applications due to its antimicrobial properties and also as anticancer drugs [17].

Some toxicological studies have, however, shown that when NPs enter into the human body through several distinct routes, including inhalation, ingestion, and dermal penetration, they can exert noticeable toxic effects at different levels of biological systems [18]. Therefore, a thorough investigation of the effects of this $\mathrm{ZnO}$ form on human health is necessary.

The aim of our study was to evaluate the effects of $\mathrm{ZnO} \mathrm{NPs}$ and conventional $\mathrm{ZnO}$ in the plus maze test as an animal model of anxiety.

\section{METHODS}

Animals and Treatment. Male albino Wistar rats weighing, on average, $200 \pm 20 \mathrm{~g}$ were obtained from the animal house of the Joundi Shapoor Medical Sciences University and accommodated for more than a week in a room at $24 \pm 1{ }^{\circ} \mathrm{C}$ with a controlled $12 / 12 \mathrm{~h}$ light-dark cycle (experiments were carried out during the light phase of the cycle). The animals were housed in polypropylene cages (four per cage). Food and drinking water were freely available (except during brief test periods). In each experiment, eight animals were used; each animal was used once only. The drugs used in the study were $\mathrm{ZnO}$ NPs $(<70 \mathrm{~nm}$, Lolitec, Germany) and cZnO (Merk, Germany). Nano ZnO and $\mathrm{cZnO}$ suspensions were prepared by sonication for $16 \mathrm{~min}$ in an ultrasonic bath; before each injection, the suspensions were shaken for $1 \mathrm{~min}$. Drugs were injected i.p. at doses of 5, 10, and $20 \mathrm{mg} / \mathrm{kg}$, while the control group received $0.9 \%$ saline $(1.0 \mathrm{ml} / \mathrm{kg})$ [19].

The size and aggregation of $\mathrm{ZnO}$ NPs were estimated in dry powder and suspension by scanning electron microscopy (Hitachi S4160, Japan), and $\mathrm{pH}$ values were measured by a $\mathrm{pH}$ meter calibrated in buffers.

Elevated Plus Maze (EPM). Behavioral testing was carried out in a dimly lighted room. Animals were adapted to the testing room for $1 \mathrm{~h}$ prior to testing. A wooden plus maze consisted of two open arms $(50 \times 10 \mathrm{~cm})$ and two closed arms of the same size (with 40-cm-high end and side walls). The arms were connected by a central $10 \times 10 \mathrm{~cm}$ area; there were no walls on the open arms. The height of the EPM above the floor was $50 \mathrm{~cm}$. Rats were placed in the center of the EPM with their head facing an open arm, left undisturbed for $5 \mathrm{~min}$, and then removed and returned to their home cages. The experimental sessions were recorded by a camera and analyzed off-line (by maze router software, Iran). A rat was considered to be on the central platform when at least two paws were on the latter and in the arm whenever all four paws were on it. The normalized values of time spent in open arms (time in open arms/time in open + closed arms) $\cdot 100 \%$ and the percentage of open arm entries, OAE (number of open arm entries/number of open + + closed arm entries) $\cdot 100 \%$ were used as measures of the anxiety level [20]. The distance traveled in close and open arms during 5 min was considered a measure of locomotor activity, LA; maze router software was used. In all experiments, the interval between injections and tests was $30 \mathrm{~min}$.

Zinc Content Analysis and $\mathbf{p H}$ Measurement in Blood Serum. By analyzing the $\mathrm{Zn}$ content and measuring $\mathrm{pH}$ in the serum $30 \mathrm{~min}$ and $24 \mathrm{~h}$ after injection, we tried to estimate effective and noneffective doses of $\mathrm{ZnO}$ NPs and compare them with the effective doses of cZnO. The animals were anesthetized by ether, and blood was collected by cardiac puncture. Then the serum was obtained by centrifugation of whole blood at $3,000 \mathrm{rpm}$ for $20 \mathrm{~min}$; $\mathrm{pH}$ was measured by a $\mathrm{pH}$ meter calibrated in a buffer, and the serum $\mathrm{Zn}$ content was analyzed by an atomic absorption spectrophotometer (Avanta, GBC, Australia). The spectrophotometer was calibrated every time by running at least five standard concentrations $(0.25,0.5,0.75,1.0$, and $1.5 \mathrm{ppm})$ of zinc.

Statistical Analysis. Numerical data were expressed as means \pm s.e.m. The Student's $t$-test was used 


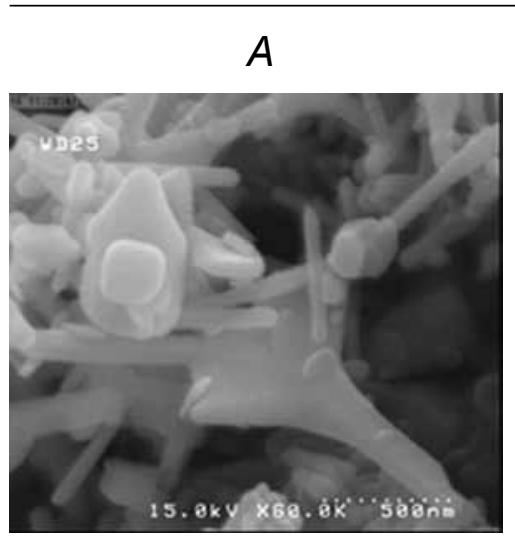

$D$

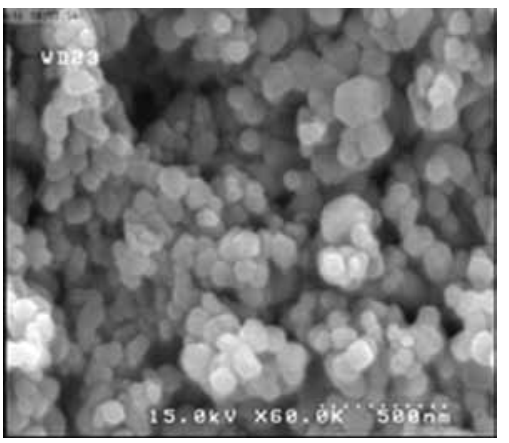

$B$

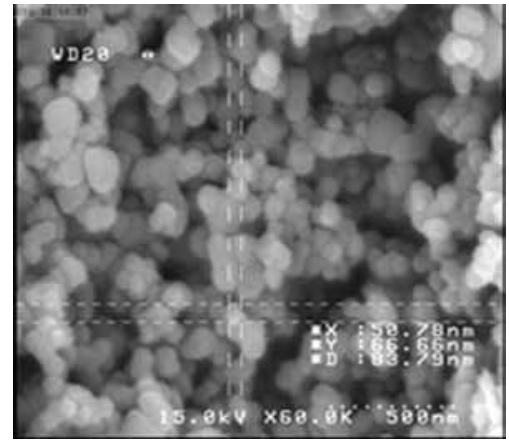

E

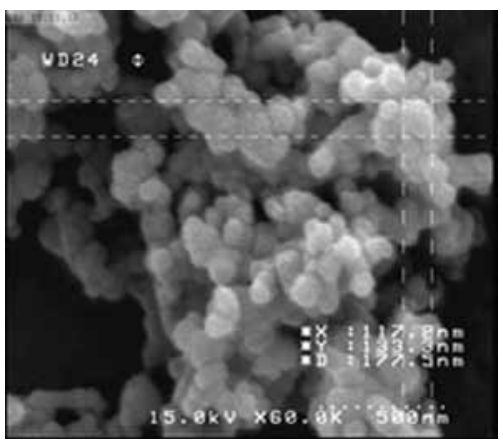

C

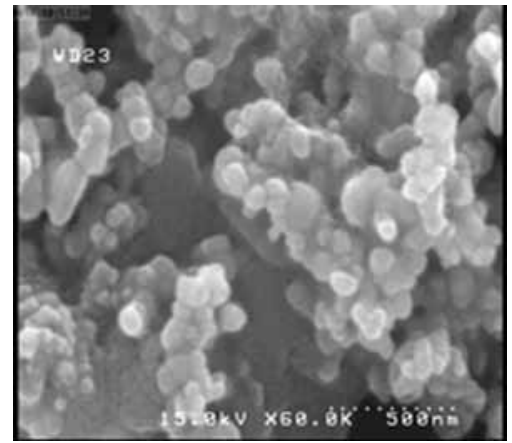

F i g. 1. SEM images of dry powders of conventional $\mathrm{ZnO}, \mathrm{cZnO}(\mathrm{A})$ and $\mathrm{ZnO}$ in the form of nanoparticles, $\mathrm{ZnO}$ NPs (B, mean particle size $<70 \mathrm{~nm}$ ) and those of suspensions with different concentrations of $\mathrm{ZnO}$ NPs, $5 \mathrm{mg} / 5 \mathrm{~cm}^{3}$ (C), $10 \mathrm{mg} / 5 \mathrm{~cm}^{3}$ (D), and $20 \mathrm{mg} / 5 \mathrm{~cm}^{3}(\mathrm{E})$; mean particle size $>133 \mathrm{~nm}$.

Р и с. 1. РЕМ-зображення сухого порошка стандартного $\mathrm{ZnO}, \mathrm{cZnO}(A)$ та $\mathrm{ZnO}$ у формі наночасток - ZnO-NP $(B$, середня величина розміру частки $<70 \mathrm{Hм}$ ), а також суспензій з різними концентраціями $\mathrm{ZnO}$ NP: $5 \mathrm{~m} / 5 \mathrm{~cm}^{3}(C), 10 \mathrm{m \Gamma} / 5 \mathrm{~cm}^{3}(D)$ та $20 \mathrm{мг} / 5 \mathrm{~cm}^{3}(E)$; середня величина розміру частки $>133$ нм. for comparison of the means of unpaired data. For multiple comparisons between groups, ANOVA was used, and the LSD post-hoc test was performed with InStat 3 software. Differences between experimental groups at each point with $P<0.05$ were considered statistically significant.

\section{RESULTS}

Determination of the dimensions of $\mathrm{ZnO}$ NPs and $\mathrm{pH}$ in suspension with different concentrations according to SEM images (Fig. 1) from cZnO dry powder (A), $\mathrm{ZnO}$ NPs (B), and ZnO NPs at different suspension concentrations $\left(5,10\right.$, and $\left.20 \mathrm{mg} / 5 \mathrm{~cm}^{3}\right)$ showed that the NPs tended to aggregate when the concentration was increased; the mean particle size increased from $<70 \mathrm{~nm}$ (in dry powder) to $>133 \mathrm{~nm}$ (at a maximum concentration, $20 \mathrm{mg} / 5 \mathrm{~cm}^{3}$ ). In addition, the $\mathrm{pH}$ of $\mathrm{ZnO}$ NPs and $\mathrm{cZnO}$ showed acidic properties, and this acidity decreased in a dose-dependent manner.

Effect of cZnO on Anxiety-like Behavior. In Fig. 2, the effects of i.p. injections of different doses of $\mathrm{cZnO}(5,10$, and $20 \mathrm{mg} / \mathrm{kg})$ are shown. Oneway ANOVA showed significant increases in OAT $(P<0.05)$ at doses of 10 and $20 \mathrm{mg} / \mathrm{kg}$ of $\mathrm{cZnO}$ (increments 66 and 52\%, as compared with the control). All doses of cZnO did not change considerably the LA and OAE indices (the OAE increased somewhat at 10 and $20 \mathrm{mg} / \mathrm{kg}$ but insignificantly). Thus, cZnO at a dose of $10 \mathrm{mg} / \mathrm{kg}$ exerted a maximum anxiolytic effect, and we selected this dose for the subsequent experiments.

Effect of ZnO NPs on Anxiety-Like Behavior. Figure 2 also shows the effects of i.p. injections of different doses of $\mathrm{ZnO} N \mathrm{NPs}$ (5, 10, and $20 \mathrm{mg} / \mathrm{kg}$ ). The first of these doses provided a significant $(72 \%)$ increase in the OAT $(P<0.05)$, while ZnO NPs in other doses did not increase this index. All doses of NPs did not influence significantly the OAE (a trend toward an increase was noticed at higher doses). $\mathrm{ZnO}$ NPs at a dose of $20 \mathrm{mg} / \mathrm{kg}$ reduced significantly LA compared with the control $(P<0.01)$. Thus, $\mathrm{ZnO}$ NPs at a dose of $5 \mathrm{mg} / \mathrm{kg}$ showed a clear anxiolytic 

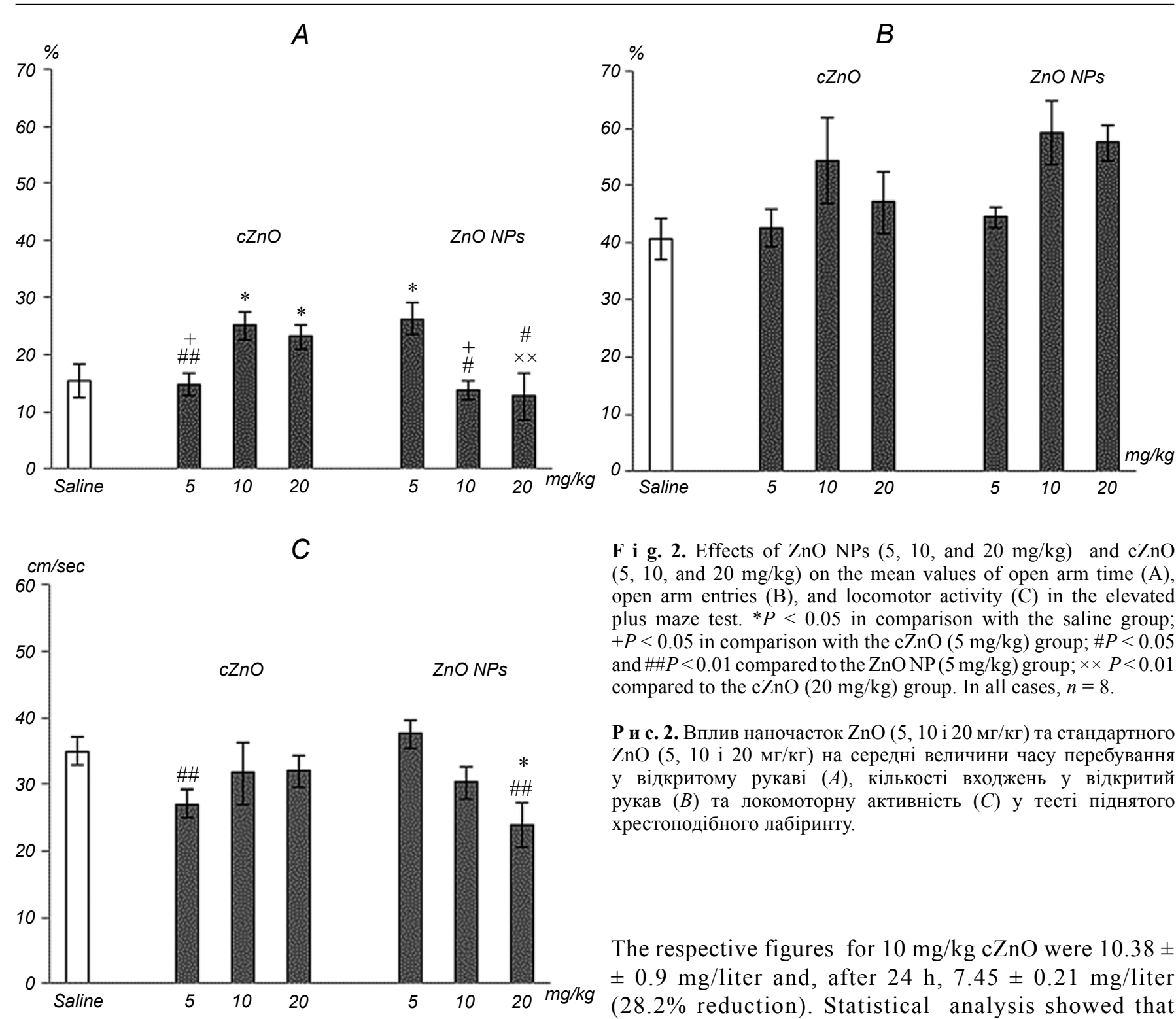

F i g. 2. Effects of $\mathrm{ZnO} \mathrm{NPs}(5,10$, and $20 \mathrm{mg} / \mathrm{kg})$ and cZnO $(5,10$, and $20 \mathrm{mg} / \mathrm{kg})$ on the mean values of open arm time (A), open arm entries (B), and locomotor activity (C) in the elevated plus maze test. ${ }^{*} P<0.05$ in comparison with the saline group; $+P<0.05$ in comparison with the $\mathrm{cZnO}(5 \mathrm{mg} / \mathrm{kg})$ group; $\# P<0.05$ and $\# \# P<0.01$ compared to the $\mathrm{ZnO} \mathrm{NP}(5 \mathrm{mg} / \mathrm{kg})$ group; $\times \times P<0.01$ compared to the $\mathrm{cZnO}(20 \mathrm{mg} / \mathrm{kg})$ group. In all cases, $n=8$.

Р и с. 2. Вплив наночасток $\mathrm{ZnO}(5,10$ і 20 мг/кг) та стандартного $\mathrm{ZnO}(5,10$ і 20 мг/кг) на середні величини часу перебування у відкритому рукаві $(A)$, кількості входжень у відкритий рукав $(B)$ та локомоторну активність $(C)$ у тесті піднятого хрестоподібного лабіринту.

The respective figures for $10 \mathrm{mg} / \mathrm{kg} \mathrm{cZnO}$ were $10.38 \pm$ $\pm 0.9 \mathrm{mg} /$ liter and, after $24 \mathrm{~h}, 7.45 \pm 0.21 \mathrm{mg} /$ liter (28.2\% reduction). Statistical analysis showed that the regression coefficient $R$ between the zinc serum concentration and anxiolytic effect was $44 \%$, while between the values of $\mathrm{pH}$ and anxiolytic effect it was

effect, and this dose was selected for the subsequent experiments.

Zinc Concentration and $\mathbf{p H}$ in the Blood Serum. There were significant differences between the serum zinc concentration and $\mathrm{pH}$ at all treatments in comparison with the control group; significant differences between the zinc concentration in treated groups depending on the doses or time were also observed. During the anxiety test, the mean serum zinc concentration at injections of $5 \mathrm{mg} / \mathrm{kg} \mathrm{ZnO}$ NPs was $5.31 \pm 0.53 \mathrm{mg} /$ liter; after $24 \mathrm{~h}$, it was reduced to $4.29 \pm 0.31 \mathrm{mg} /$ liter $(19.21 \%$ reduction); at a dose of NPs of $10 \mathrm{mg} / \mathrm{kg}$, this index was $22.3 \pm 2.6 \mathrm{mg} /$ liter.

\section{DISCUSSION}

The elevated plus maze (EPM) test is one of the most popular tests for all currently available animal models in neurobiological anxiety research; it is used as a screening test for putative anxiolytic or anxiogenic compounds [21]. Our results showed that acute injection of $\mathrm{ZnO}$ NPs in the lowest dose $(5 \mathrm{mg} / \mathrm{kg})$ and $\mathrm{cZnO}$ in greater doses (10 and $20 \mathrm{mg} / \mathrm{kg}$ ) induced anxiolytic effects in the EPM test in adult male rats. 
Some studies agree with our results. For example, it was shown that dietary zinc deficiency in mice induced anxiety-related behavior in the novelty-suppressed feeding test measured as enhanced latencies to eat $[8,9]$. It was also shown that 2-month-long feeding with high levels of zinc supplements, such as zinc methionine, $\mathrm{ZnSO}_{4}$, and $\mathrm{ZnO}$, reduced anxiety in rats subjected to the EPM test [10].

Figure 2 shows that equal doses of $\mathrm{ZnO}$ NPs and $\mathrm{cZnO}$ exert dissimilar effects on anxiety behavior, and the efficacies of equal doses do not overlap. The anxiolytic dose of $\mathrm{ZnO}$ NPs corresponds to half of the anxiolytic dose of $\mathrm{cZnO} ; 5 \mathrm{mg} / \mathrm{kg} \mathrm{cZnO}$ exerts no effect on anxiety. These differences may be due to the small size of ZnO NPs and different physicochemical properties in comparison with those of the conventional form. As a result, $\mathrm{ZnO}$ NPs possessing greater mobility and uptake across biological membranes can interact more strongly with biological tissues [22, 23]. The greater surface area of nanoparticles provides more reactive groups and higher reactivities than the conventional $\mathrm{ZnO}$ form [24].

Our data also showed that all doses of $\mathrm{cZnO}$ and 5 and $10 \mathrm{mg} / \mathrm{kg} \mathrm{ZnO}$ NPs did not change significantly LA, while $20 \mathrm{mg} / \mathrm{kg} \mathrm{ZnO} \mathrm{NPs} \mathrm{reduced} \mathrm{this} \mathrm{activity}$ with practically no change in anxiety-like behavior. Thus, the anxiolytic effects of $\mathrm{cZnO}$ and $\mathrm{ZnO}$ NPs are not related to of LA modulation. Higher doses of $\mathrm{ZnO}$ NPs increased significantly the serum zinc concentration but provided no changes in the anxiety indices. This finding indicates that the lowest dose of $\mathrm{ZnO}$ NPs used released enough zinc to act on the respective receptor structures; moreover, higher doses are likely to saturate the serum zinc level but reduce the anxiolytic effect, which agrees with our previous results [25].

We found that in all treated groups the $\mathrm{pH}$ increased in comparison to that in the control group, but there were no significant differences between $\mathrm{pH}$ in all treated groups. Furthermore, statistical analysis did not show any correlation between the anxiety parameters and $\mathrm{pH}$. This fact indicates that increased $\mathrm{pH}$ did not affect the anxiety level in our study. After $24 \mathrm{~h}$, the reduction of the zinc concentration in the $\mathrm{ZnO} \mathrm{NP}$ groups was lower than that of $\mathrm{cZnO}$; thus, it seems that the clearance of $\mathrm{ZnO} N P s$ is less than that of $\mathrm{cZnO}$ [25]. Thus, the efficacy of $\mathrm{ZnO}$ NPs with respect to the reduction of anxiety may depend on the $\mathrm{ZnO}$ structure and longer bioavailability more than on its concentration [26]. In addition, SEM images showed that, with rising aggregation at higher $\mathrm{ZnO}$ NP concentrations, the anxiolytic effects decreased. Thus, ZnO NP pharmacokinetics need more investigation [25].

Our unpublished data also showed that, 10 days after acute administration of these drugs, there were no mortality, loss of weight, or considerable visible impairments in the health status of the animals, suggesting that injections of these doses of the drugs are at least not lethal.

The anxiolytic effect of $\mathrm{ZnO} \mathrm{NPs}$ or $\mathrm{cZnO}$ may be due to the role of zinc in the anxiety-related neurochemical systems. In presynaptic spaces, zinc is co-released with glutamate, and zinc is an inhibitory neuromodulator in the glutamate signalling system [27, 28]. A number of studies indicated that glutamate is an important factor in the formation of anxiety and anxious behavior. Blocking of glutamate NMDA receptors can elicit a significant anxiolytic effect [29]. Several studies demonstrated that stimulation of NMDA receptors induces anxiogeniclike behaviors in a variety of animal models of anxiety [30]. Administration of competitive and noncompetitive NMDA receptor antagonists induced anxiolytic behaviors in humans and laboratory animals [30]. Electrophysiological studies showed that zinc weakens the NMDA receptor-mediated response via two different mechanisms, voltage-independent noncompetitive (allosteric) inhibition responsible for reducing the channel opening frequency, and voltagedependent inhibition representing the open-channel blocking effect of zinc [31]. Therefore, the release of zinc together with glutamate reduces the ability of glutamate to activate postsynaptic NMDA receptors.

Interestingly, $\mathrm{Li}$ et al. [32] showed that, in the experiments combining zinc imaging with electrophysiological recording during electrical stimulation of rat hippocampus $C A 3$ slices, the release of zinc from mossy fiber terminals occurs in a certain synaptic region of the dendrites (stratum lucidum) that is rich with NMDA receptors. Therefore, we suggest that exposure to $\mathrm{ZnO}$ particles inhibits glutamate influences on NMDA receptors (an important neurochemical system is anxious animals).

Another alternative way to decrease the glutamate output in the CNS can be achieved by intensification of GABA neurotransmission. A balance between GABA receptor-mediated inhibition and glutamate receptor-mediated excitation can regulate behavioral and physiological responses associated with anxiety $[33,34]$. Zinc promotes the release of GABA from interneurons in the hippocampus, thus enhancing the inhibitory effects of this neurotransmitter and leading 
to decrease in presynaptic release of glutamate [35]. As a result, the release of zinc from $\mathrm{cZnO}$ and $\mathrm{ZnO}$ NPs in our study is likely to be responsible for reducing the anxiety level via a reduction in the release of glutamate and blocking of NMDA receptor and/or via increase in the release of GABA and disrupting the balance between glutamate and an GABA in the CNS.

Thus, our study showed that the efficacy of $\mathrm{ZnO}$ NPs to reduce anxiety is much greater than that of conventional $\mathrm{ZnO}$ introduced in an equal dose. Increasing doses of $\mathrm{ZnO}$ NPs do not increase their efficacy from the above aspect. The beneficial effects of this $\mathrm{ZnO}$ form may be related to the specific size and structure or selectivity with respect to specific target.

All experimental procedures were carried out in accordance with international and institutional guidelines for animal care and use.

The authors, M. Torabi, M. Kesmati, H. E. Harooni, and H. N. Varzi, have no conflict of interests.

This study was supported by the Shahid Chamran University of Ahvaz, Iran, grants No. 90/302/18672, June 7, 2011. Hereby, researchers of this study would like to express their sincere gratitude to the Esteemed Vice-presidency for Research of Shahid Chamran University for their financial and moral supports .Thanks are due to Dr. Nahid Pour Reza and Dr. Seyyd Mansour Syednejad from the Department of Chemistry and Biology for their laboratory supports.

\section{M. Торабі ${ }^{1}$, M. Кесматі ${ }^{l}$, Х. Е. Харуні ${ }^{1}$, Х. T. Варзі ${ }^{2}$}

\section{ВПЛИВ ZnO У ФОРМІ НАНОЧАСТОК ТА СТАНДАРТНОГО ZnO НА ПОВ' ЯЗАНУ 3 ТРИВОГОЮ ПОВЕДІНКУ У ЩУРІВ}

\footnotetext{
${ }^{1}$ Відділ біології, факультет наук, Університет Шахід Шамран, Ахваз (Іран).

${ }^{2}$ Відділ фармакології, факультет ветеринарної медицини, Університет Шахід Шамран, Ахваз (Іран).
}

P е 3 ю м е

Як було показано, додавання мікроелементу цинку (наприклад, у формі окису цинку, $\mathrm{ZnO}$ ) може істотно впливати на рівень тривожності. Ми досліджували вплив $\mathrm{ZnO}$ у формі наночасток (НЧ) порівняно зі стандартним $\mathrm{ZnO}$ $(\mathrm{cZnO})$ на пов'язану з тривогою поведінку у щурів. Дорослі щури лінії Вістар були поділені на сім груп - контрольну групу (тварини отримували фізіологічний розчин) та шість груп щурів, котрі отримували 5, 10 та 20 мг/кг ZnOНЧ, а також 5, 10 та 20 мг/кг cZnO. Усі дисперговані у 0.9 \%-му фізіологічному розчині препарати ін'єкували внутрішньоочеревинно; через 30 хв після ін'єкції рівень тривоги оцінювали згідно з результатами тесту піднятого хрестоподібного лабіринту. ZnO-НЧ (5 мг/кг) i c ZnO (10 та 20 мг/кг) істотно збільшували нормовані величини часу перебування у відкритих рукавах (\%) порівняно з таким показником у контрольній групі $(P<0.05)$. Це свідчить про анксіолітичні ефекти обох агентів; крім того, $\mathrm{ZnO}-\mathrm{HЧ}$ (20 мг/кг) послаблював локомоторну активність $(P<0.05)$. Концентрація цинку в сироватці при дії агентів у анксіолітичних дозах була багаторазово збільшеною. Усі дози збільшували рН сироватки до 8.05-8.10 та підтримували цей показник на постійному рівні протягом 24 год. Наші результати вказують на те, що інтенсивність анксіолітичного ефекту ZnO-HЧ є набагато більшою, ніж інтенсивність дії стандартної форми ZnO. Застосування ZnO-HЧ у якості нового терапевтичного препарату у разі тривожних неврозів потребує подальшого дослідження.

\section{REFERENCES}

1. R. C. Kessler, W. T. Chiu, O. Demler, and E. E. Walters, "Prevalence, severity, and comorbidity of 12-month DSM-IV disorders in the National Comorbidity Survey Replication," Arch. Gen. Psychiat., 62, No. 6, 617-627 (2005).

2. T. E. Moffitt, H. Harrington, A. Caspi, et al., "Depression and generalized anxiety disorder: cumulative and sequential comorbidity in a birth cohort followed prospectively to age 32 years," Arch. Gen. Psychiat., 64, No. 6, 651-660 (2007).

3. A. Takeda, "Movement of zinc and its functional significance in the brain," Brain. Res. Rev., 34, No. 3, 137-148 (2000).

4. N. L. Harrison and S. J. Gibbons, " $\mathrm{Zn}^{2+}$ : an endogenous modulator of ligand- and voltage-gated ion channels," Neuropharmacology, 33, 935-952 (1994).

5. J. Magistretti, L. Castelli, V. Taglietti, and F. Tanzi, "Dual effect of $\mathrm{Zn}^{2+}$ on multiple types of voltage-dependent $\mathrm{Ca}^{2+}$ currents in rat palaeocortical neurons," Neuroscience, 117, No. 2, 249-264 (2003).

6. T. G. Smart, X. Xie, and B. J. Krishek, "Modulation of inhibitory and excitatory amino acid receptor ion channels by zinc," Prog. Neurobiol., 42, 393-441 (1994).

7. A. S. Prasad, "Discovery of human zinc deficiency: 50 years later," J. Trace. Elem. Med. Biol., 26, 66-69 (2012).

8. N. M Tassabehji., R. S. Corniola, A. Alshingiti, and C. W. Levenson, "Zinc deficiency induces depression-like symptoms in adult rats," Physiol. Behav., 95, No. 3, 365-369 (2008).

9. N. Whittle, G. Lubec, and N. Singewald, "Zinc deficiency induces enhanced depression-like behavior and altered limbic activation reversed by antidepressant treatment in mice," Amino Acids, 36, No. 1, 147-158 (2009).

10. S. Sobhanirad, R. Valizade, A. Moghimi, and A. Tahmasebi, "Evaluation of the anxiolytic effects of zinc supplemented diet in the elevated plus-maze test," Res. J. Biol. Sci., 3, No. 9, 964-967 (2008).

11. H. M. Edwards and D. H. Baker, "Bioavailability of zinc in several sources of zinc oxide, zinc sulfate, and zinc metal," J. Anim. Sci., 77, No. 10, 2730-2735 (1999).

12. M. V. Do Carmo E Sб, L. E. Pezzato, M. M. Barros, and N/ P. P. De Magalhres Padilha, "Relative bioavailability of zinc in supplemental inorganic and organic sources for Nile 
tilapia, Oreochromisniloticus fingerlings," Aquacult. Nutr., 11, No. 4, 273-281 (2005).

13. C. M. Sayes, K. L. Reed, and D. B. Warheit, "Assessing toxicity of fine and nanoparticles: comparing in vitro measurements to in vivo pulmonary toxicity profiles," Toxicol. Sci., 97, No. 1, 163-180 (2007).

14. A. Nel, T. Xia, L. Mдdler, and N. Li, "Toxic potential of materials at the nanolevel," Science, 311, No. 5761, 622-627 (2006).

15. T. Jin, D. Sun, J. Y. Su, et al., "Antimicrobial efficacy of zinc oxide quantum dots against Listeria monocytogenes, Salmonella enteritidis, and Escherichia coli O157:H7," J. Food. Sci., 74, No. 1, 46-52 (2009).

16. L. Yan, F. Zhao, S. J. Li, et al., "Low-toxic and safe nanomaterials by surface-chemical design, carbon nanotubes, fullerenes, metallofullerenes and graphenes," Nanoscale, $\mathbf{3}$, No. 2, 362-382 (2011).

17. J. W. Rasmussen, E. Martinez, P. Louka, and D. G. Wingett, "Zinc oxide nanoparticles for selective destruction of tumor cells and potential for drug delivery applications," Expert. Opin. Drug. Deliv., 7, No. 9, 1063-1077 (2010).

18. H. J. Wang, A. C. Growcock, T. H. Tang, et al., "Zinc oxide nanoparticle disruption of store-operated calcium entry in a muscarinic receptor signaling pathway," Toxicol. In Vitro, 24, No. 7, 1953-1961 (2010).

19. A. O. Rosa, J. Lin, J. B. Calixto, et al., "Involvement of NMDA receptors and L-arginine-nitric oxide pathway in the antidepressant-like effects of zinc in mice," Behav. Brain. Res., 144, 87-93 (2003).

20. M. R. Zarrindast, Sahand Babapoor-Farrokhran, Savalan Babapoor-Farrokhran, and A. Rezayof, "Involvement of opioidergic system of the ventral hippocampus, the nucleus accumbens or the central amygdala in anxiety-related behavior," Life. Sci., 82, 1175-1181 (2008).

21. M. Mard-Soltani, M. Kesmati, L. Khajehpour, et al., "Interaction between anxiolytic effect of testosterone and $\beta-1$ adrenoceptors of basolateral amygdala," Int. J. Pharmacol., 8, No. 5, 344-354 (2012).

22. G. Sonavane, K. Tomoda, and K. Makino, "Biodistribution of colloidal gold nanoparticles after intravenous administration: effect of particle size," Colloids. Surf., B, Biointerfaces, 66, 274-280 (2008).
23. B. D. Chithrani, A. A. Ghazani, and W. C. W. Chan, "Determining the size and shape dependence of gold nanoparticle uptake into mammalian cells," Nano Lett., 4, 662668 (2006).

24. S. Arora, J. M. Rajwade, and K. M. Paknikar, "Nanotoxicology and in vitro studies: The need of the hour," Toxicol. Appl. Pharmacol., 258, No. 2, 151-165 (2012).

25. X. Peng, S. Palma, N. S. Fisher, and S. S. Wong, "Effect of morphology of $\mathrm{ZnO}$ nanostructures on their toxicity to marine algae," Aquat. Toxicol., 102, Nos. 3/4, 186-196 (2011).

26. P. Decuzzi, F. Causa, M. Ferrari, and P. A. Netti, "The effective dispersion of nanovectors within the tumor microvasculature," Ann. Biomed. Eng., 34, No. 4, 633-641 (2006).

27. A. Takeda and H. Tamano, "Insight into zinc signaling from dietary zinc deficiency," Brain. Res. Rev., 62, No. 1, 33-44 (2009).

28. P. Paoletti, A. M. Vergnano, B. Barbour, and M. Casado, "Zinc at glutamatergic synapses," Neuroscience, 158, No. 1, 126-136 (2009).

29. V. Bergink, H. J. G. M. Van Megen, and H. G. M. Westenberg, "Glutamate and anxiety," Eur. Neuropsychopharmacol., 14, 175-183 (2004).

30. C. M. Padovan, E. A. Del Bel, and F. S. Guimaraes, "Behavioral effects in the elevated plus maze of an NMDA antagonist injected into the dorsal hippocampus: influence of restraint stress," Pharmacol. Biochem. Behav., 67, No. 2, 325330 (2000).

31. J. Y. Koh and D. W. Choi, "Zinc toxicity on cultured cortical neurons: Involvement of N-methyl-D-aspartate receptors," Neuroscience, 60, No. 4, 1049-1057 (1994).

32. Y. V. Li, C. J. Hough, and J. M. Sarvey, "Do we need zinc to think?" Sci. STKE, 182, 19 (2003).

33. M. Rezvanfard, M. R. Zarrindast, and P. Bina, "Role of ventral hippocampal GABA(A) and NMDA receptors in the anxiolytic effect of carbamazepine in rats using the elevated plus maze test," Pharmacology, 84, No. 6, 356-366 (2009).

34. A. Takeda, M. Hirate, H. Tamano, and N. Oku, "Release of glutamate and GABA in the hippocampus under zinc deficiency," J. Neurosci. Res., 72, 537-542 (2003).

35. A. Takeda, A. Minami, Y. Seki, and N. Oku, "Differential effects of zinc on glutamatergic and GABAergic neurotransmitter systems in the hippocampus," J. Neurosci. Res., 75, 225-229 (2004). 